\title{
INFLUENCE OF CITRIC ACID AND HYDROGEN PEROXIDE ON POSTHARVEST QUALITY OF TUBEROSE (Polianthes TUbERosa L. 'PEARL') CUT FLOWERS
}

\author{
Abdolrahman RAHIMIAN-BOOGAR ${ }^{1,2 *}$, Hassan SALEHI ${ }^{1}$, Noshin MIR ${ }^{3}$ \\ ${ }^{1}$ Department of Horticulture Science, College of Agriculture, Shiraz University, Shiraz, Iran \\ ${ }^{2}$ Department of Horticulture Science, College of Agriculture, Zabol University, Zabol, Iran \\ ${ }^{3}$ Department of Chemistry, University of Zabol, Zabol, Iran
}

Received: October 2015; Accepted: May 2016

\begin{abstract}
Quality of cut flowers is an important issue at postharvest as well as an important factor contributing to marketing of and profitability from the tuberose. In this study, the effects of citric acid (CA) and hydrogen peroxide $\left(\mathrm{H}_{2} \mathrm{O}_{2}\right)$ added to the vase water on postharvest quality of tuberose cut flowers were investigated. CA was applied in concentrations of $50,100,200,400 \mathrm{mg} \cdot \mathrm{dm}^{-3}$ and $\mathrm{H}_{2} \mathrm{O}_{2}$ in concentrations of 10, 20, 40 and $80 \mathrm{mg} \cdot \mathrm{dm}^{-3}$ and distilled water as control treatment. Results showed that both compounds had significant positive effects on solution uptake, wilting and abscission of florets, relative water content, chlorophyll content, and vase life duration. The effects of 100 and $200 \mathrm{mg} \cdot \mathrm{dm}^{-3}$ of CA and 20 and $40 \mathrm{mg} \cdot \mathrm{dm}^{-3} \mathrm{of} \mathrm{H}_{2} \mathrm{O}_{2}$ proved to be more effective than other treatments. Both compounds increased the vase life of tuberose cut flowers and CA at concentrations 100 and $200 \mathrm{mg} \mathrm{dm}^{-3}$ and $\mathrm{H}_{2} \mathrm{O}_{2}$ at concentrations 20 and $40 \mathrm{mg} \mathrm{dm}^{-3}$ doubled this time up to 14-17 days.
\end{abstract}

Key words: postharvest treatment, postharvest quality, tuberose

\section{INTRODUCTION}

Tuberose (Polianthes tuberosa L.) is a perennial bulbous plant of Asparagaceae. Tuberose is a popular and commercially valuable cut flower produced worldwide (De Hertogh \& Le Nard 1993; Cuc \& Pilon 2007; Cuc et al. 2010; Taha \& Eid 2011; Bahadoran et al. 2012). Extending the vase life after harvest is a significant issue that has a major impact on efficient trading of cut flowers and can increase the economic benefits (Weaver et al. 1998). In the cut flowers of tuberose, wilting and burning of florets and bending of the tips of flower spikes are the major problems that reduce the vase life of cut flowers (Jowkar \& Salehi 2005). Various factors such as ethylene sensitivity, bacterial contamination, vascular blockage, and oxidative stress cause petal burning or browning, and floret wilting or abscission in cut flowers (Rubinstein 2000; Sankhla et al. 2003; Rattanawisalanon et al. 2003; Rogers
2006; Zhang et al. 2011; Shahri \& Tahir 2011). Moreover, various agents such as microbial activities, air obstruction and physiological response to cutting wound, gum aggregation in xylem, latex leakage, and other processes in the wound lead to vascular blockage and prevent water uptake, which reduces the freshness of cut flowers (Rattanawisalanon et al. 2003; van Ieperen et al. 2002; van Meeteren et al. 2005; van Meeteren et al. 2006; Imsabai et al. 2013). Additionally, recent studies on some cut flowers demonstrated that, with decrease in the freshness of cuts, some bacteria aggregate in the vase solution and lead to senescence of cut flowers (Macnish et al. 2008). By using some acids as antibacterial compounds, the frequency of bacteria in the vase solution can be decreased and the vase life of various cut flowers significantly increased, which is supposedly due to the reduction in vascular blockage (Alaey et al. 2011; Shimizu-Yumoto \& Ichimura 2010; Mansouri 2012). 
Van Doorn (2010) showed that decrease in the $\mathrm{pH}$ of preservation solutions reduced the rate of bacterial growth and increased the water conduction in xylem of cut flowers. Furthermore, a low concentrations of hydrogen peroxide $\left(\mathrm{H}_{2} \mathrm{O}_{2}\right)$ was used as a biocontrol agent to counter several abiotic and oxidative stresses during the postharvest time (Macarisin et al. 2010; Peng et al. 2008). $\mathrm{H}_{2} \mathrm{O}_{2}$ is an essential molecule, which is involved in a plant's growth and development (Neill et al. 2002). An addition of the $\mathrm{H}_{2} \mathrm{O}_{2}$ into the preservation solution of lily cut flower led to maintaining the cut flower quality and increasing the vase life (Liao et al. 2012).

The aim of this study was to evaluate the effects of citric acid (CA) and $\mathrm{H}_{2} \mathrm{O}_{2}$ on postharvest characteristics of tuberose cut flowers. To the best of our knowledge, this is the first report on using exogenous $\mathrm{H}_{2} \mathrm{O}_{2}$ and $\mathrm{CA}$ on tuberose cut flowers in order to extend the vase life and maintain the postharvest quality.

\section{MATERIAL AND METHODS}

\section{Experimental material}

Tuberose plants (P. tuberosa cv. 'Pearl') were cultivated in a greenhouse with air temperature set at $25-30{ }^{\circ} \mathrm{C}$ during the daytime and $20-25{ }^{\circ} \mathrm{C}$ during the nighttime and a relative humidity of $60 \%$. Flower shoots were harvested in the phase of 1-2 opened 1-2 florets. After cutting the flowers from mother plants, they were transferred to the research laboratory in the Agricultural Faculty of Zabol University. The laboratory temperature was controlled at around $18-22{ }^{\circ} \mathrm{C}$ and $55-60 \%$ relative humidity, and fluorescent light was set for 12-hour lighting. The experiments were carried out with no stem recutting and no changing of the vase solutions during three weeks.

\section{Postharvest treatments}

Flower shoots were placed separately in 200$\mathrm{ml}$ bottles containing the $\mathrm{CA}(50,100,200$, and $\left.400 \mathrm{mg} \cdot \mathrm{dm}^{-3}\right), \mathrm{H}_{2} \mathrm{O}_{2}\left(10,20,40\right.$, and $\left.80 \mathrm{mg} \cdot \mathrm{dm}^{-3}\right)$, or distilled water as the control treatment.

\section{Measured characteristics}

The parameters evaluated at the end of the experiment (after three weeks) included vase life duration; percentage of opened, wilted and abscised florets; relative chlorophyll content using SPAD detection method measured on the first big leaf under inflorescence according to Coste et al. (2010); solution uptake; fresh weight; and relative water content (RWC) (Sairam et al. 2002). Before use, the SPAD was calibrated with an empirical relationship between SPAD unit and chlorophyll content by a homographic model. The homographic model was parameterized on the collected data set $(\mathrm{N}=$ 45 samples).

$$
C h l_{i}=\left(\alpha \operatorname{SPAD}_{\mathrm{i}} /\left(\beta-\mathrm{SPAD}_{\mathrm{i}}\right)\right)+\varepsilon_{\mathrm{i}}
$$

$\mathrm{Chl}_{\mathrm{i}}$ is the total content of chlorophyll ( $\mathrm{a}$ and $\mathrm{b}$ ), $\alpha$ and $\beta$ are parameters of the homographic models, and $\mathrm{SPAD}_{\mathrm{i}}$ is the unitless reading from the SPAD502 meter.

\section{Experimental design and data analysis}

Experiments were conducted in a complete randomized design with five replicates per treatment and two repetitions of the whole experiment in May and September 2015. Data were analyzed by SPSS-v.19 software with one-way analysis of variance test for $\mathrm{CA}$ and $\mathrm{H}_{2} \mathrm{O}_{2}$ separately. Furthermore, analysis of post-hoc Duncan test of general linear model univariate was used for input the comparisons effects of both biocides on postharvest of tuberose cut flower.

\section{RESULTS}

Data analysis showed significant effects of CA and $\mathrm{H}_{2} \mathrm{O}_{2}$ on the most measured characteristics of tuberose cut flowers. The only exceptions were, no effect of both compounds on fresh weight and $\mathrm{H}_{2} \mathrm{O}_{2}$ on the solution uptake (Table 1).

Table 1: $F$ statistics from ANOVA for tested traits

\begin{tabular}{lcc}
\hline \multirow{2}{*}{ Trait } & \multicolumn{2}{c}{ Source of variation } \\
\cline { 2 - 3 } & Citric acid & $\mathrm{H}_{2} \mathrm{O}_{2}$ \\
\hline Solution uptake (ml) & $3.911^{*}$ & $2.549 \mathrm{~ns}$ \\
Fresh weight (\% of initial value) & $1.172 \mathrm{~ns}$ & $1.732 \mathrm{~ns}$ \\
Relative water content (\%) & $15.375^{* *}$ & $7.742^{* *}$ \\
Wilting of florets (\%) & $6.437^{* *}$ & $16.274^{* *}$ \\
Abscission of florets $(\%)$ & $28.724^{* *}$ & $29.755^{* *}$ \\
Chlorophyll content $\left(\mathrm{mg} \cdot \mathrm{cm}^{-2}\right)$ & $43.564^{* *}$ & $26.238^{* *}$ \\
Vase life duration (days) & $12.841^{* *}$ & $18.489^{* *}$ \\
\hline
\end{tabular}

ns - not significant, $* \mathrm{p}>0.05, * * \mathrm{p} \leq 0.05$ 


\section{Solution uptake, fresh weigh of cut flowers, and relative water content in leaves}

$\mathrm{CA}$ at a concentration of $100 \mathrm{mg} \cdot \mathrm{dm}^{-3}$ increased solution uptake by tuberose cut flowers $\left(\mathrm{F}_{4,20}=3.911, \mathrm{P}<0.05\right)$, while $\mathrm{H}_{2} \mathrm{O}_{2}$ did not influence this trait (Table 1, Fig. 1). $\mathrm{H}_{2} \mathrm{O}_{2}$ and CA did not have a significant effect on fresh weight $\left(\mathrm{F}_{4,20}=1.172\right.$ and $\mathrm{F}_{4,20}=1.732$, respectively) (Table 1, Fig. 2). The studied compounds significantly affected RWC of cut flowers during postharvest time [CA $\left(\mathrm{F}_{4,20}=15.375, \mathrm{P}<0.01\right) ; \mathrm{H}_{2} \mathrm{O}_{2}\left(\mathrm{~F}_{4,20}=7.742\right.$, $\mathrm{P}<0.01)$ ] (Table 1). However, the effects differed between treatments (Fig. 3). The RWC increased at 50,100 , and $200 \mathrm{mg} \cdot \mathrm{dm}^{-3}$ of CA and at $20 \mathrm{mg} \cdot \mathrm{dm}^{-3}$ of $\mathrm{H}_{2} \mathrm{O}_{2}$.

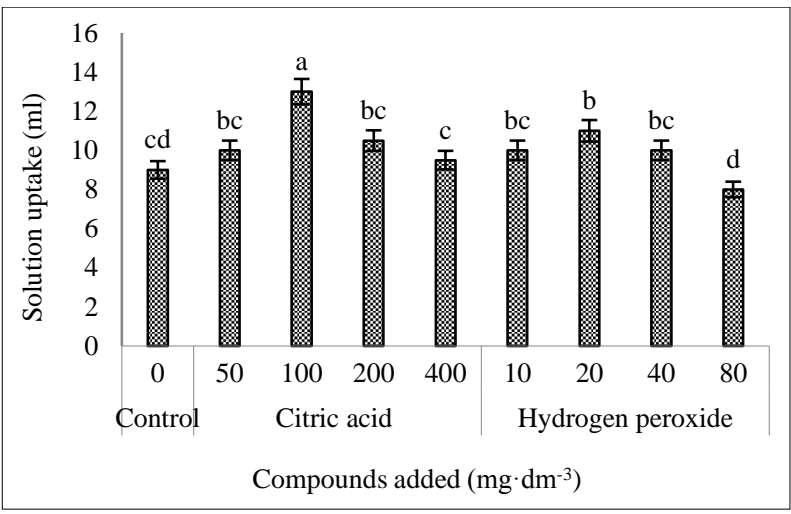

Fig. 1. Effects of citric acid and hydrogen peroxide on solution uptake by tuberose cut flowers. Bars indicating by the same letter do not differ significantly according to Duncan's multiple range test at $p=0.05$, vertical lines - SE

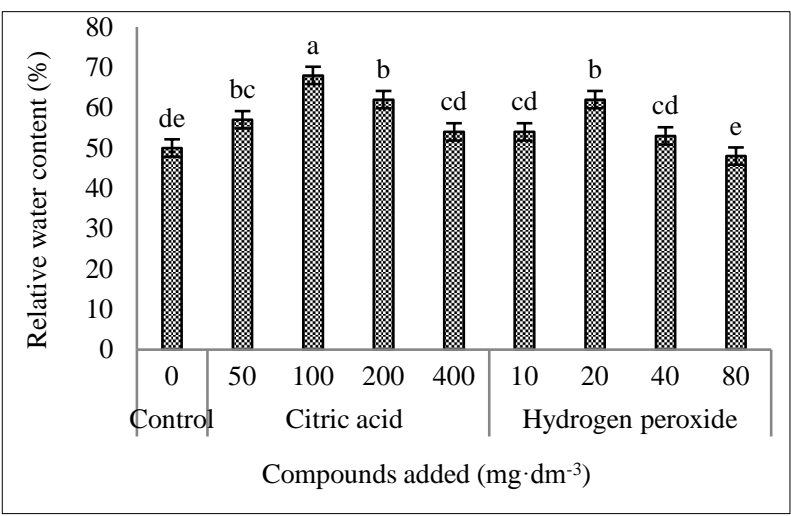

Fig. 3. Effects of citric acid and hydrogen peroxide on relative water content of tuberose cut flowers. Bars indicating by the same letter do not differ significantly according to Duncan's multiple range test at $\mathrm{p}=0.05$, vertical lines $-\mathrm{SE}$

\section{Percentage of the florets wilting and abscission}

Application of CA and $\mathrm{H}_{2} \mathrm{O}_{2}$ significantly impacted the wilting of florets $\left(\mathrm{CA}: \mathrm{F}_{4,20}=6.437\right.$, $\mathrm{P}<0.01 ; \mathrm{H}_{2} \mathrm{O}_{2}: \mathrm{F}_{4,20}=16.274, \mathrm{P}<0.01$, respectively) (Table 1). CA at all concentrations and $\mathrm{H}_{2} \mathrm{O}_{2}$ at 20,40 , and $80 \mathrm{mg} \cdot \mathrm{dm}^{-3}$ decreased flowers wilting (Fig. 4). At $200 \mathrm{mg} \cdot \mathrm{dm}^{-3}$ of CA, about $17 \%$ of florets wilted, and at $20 \mathrm{mg} \cdot \mathrm{dm}^{-3}$ of $\mathrm{H}_{2} \mathrm{O}_{2}$, about $12 \%$ flowers wilted in comparison to $25 \%$ in the control without additions. The abscission of florets was retarded by the addition of CA and $\mathrm{H}_{2} \mathrm{O}_{2}$ at all concentrations, with the greatest decrease at $100 \mathrm{mg} \cdot \mathrm{dm}^{-3}$ of CA, and at 20 and $40 \mathrm{mg} \cdot \mathrm{dm}^{-3}$ of $\mathrm{H}_{2} \mathrm{O}_{2}$ to about $15 \%$, while in the control, about $33 \%$ of florets abscised (Fig. 5).

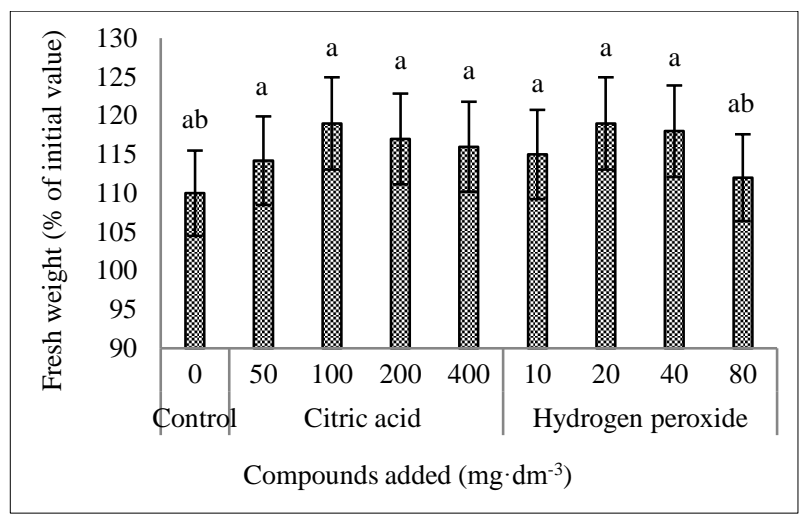

Fig. 2. Effects of citric acid and hydrogen peroxide on fresh weight of tuberose cut flowers. Bars indicating by the same letter do not differ significantly according to Duncan's multiple range test at $\mathrm{P}=0.05$, vertical lines $-\mathrm{SE}$

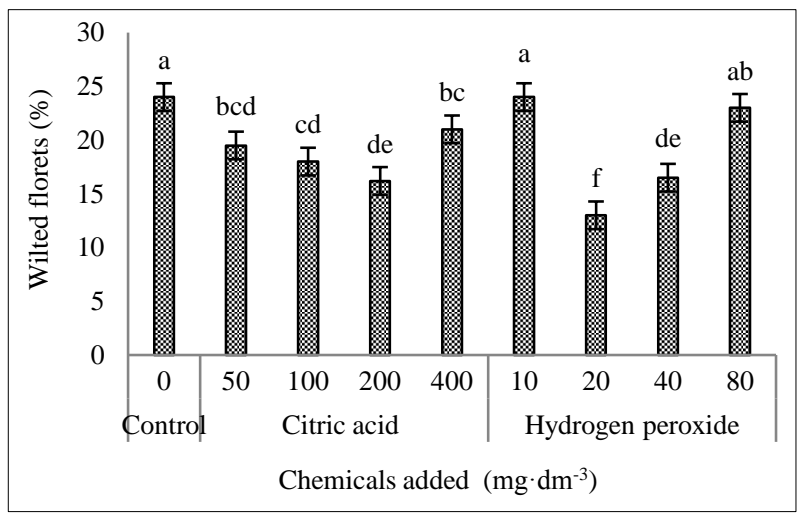

Fig. 4. Effects of citric acid and hydrogen peroxide on wilting of florets of tuberose cut flowers. Bars indicated by the same letter do not differ significantly according to Duncan's multiple range test at $\mathrm{P}=0.05$, vertical lines $-\mathrm{SE}$ 


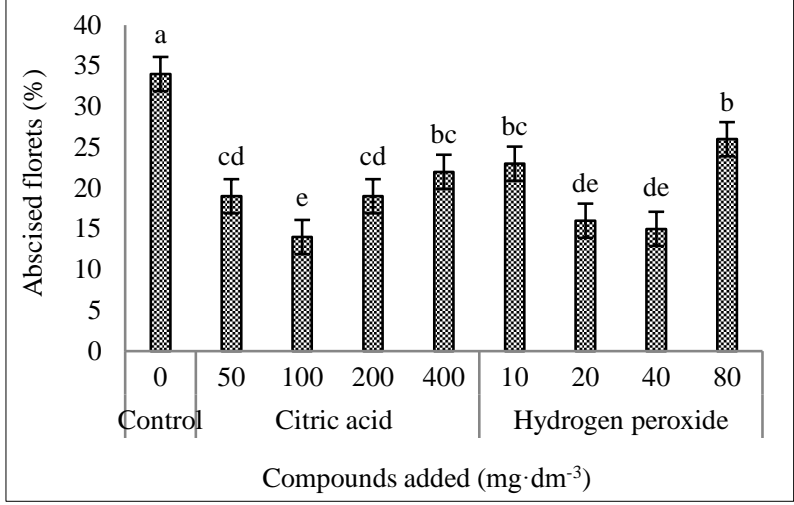

Fig. 5. Effects of citric acid and hydrogen peroxide on abscission of florets of tuberose cut flowers. Bars indicated by the same letter do not differ significantly according to Duncan's multiple range test at $\mathrm{P}=0.05$, vertical lines $-\mathrm{SE}$

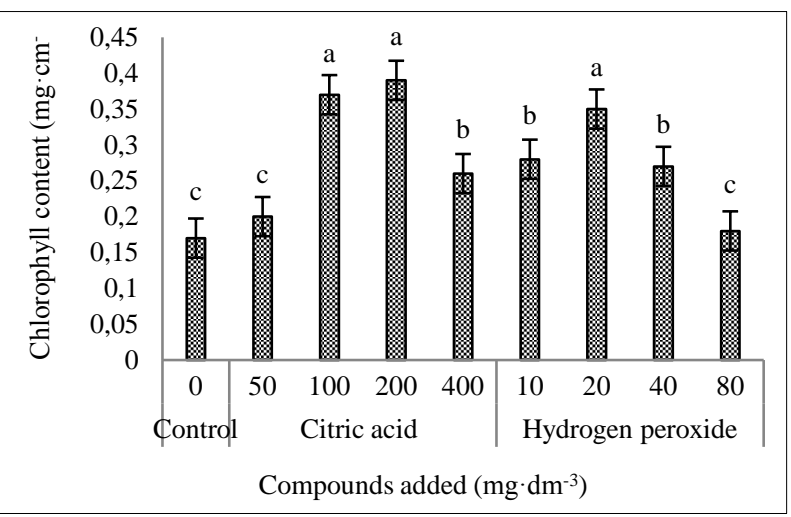

Fig. 6. Effects of citric acid and hydrogen peroxide on chlorophyll content of tuberose cut flowers. Bars indicated by the same letter do not differ significantly according to Duncan's multiple range test at $\mathrm{P}=0.05$, vertical lines - SE

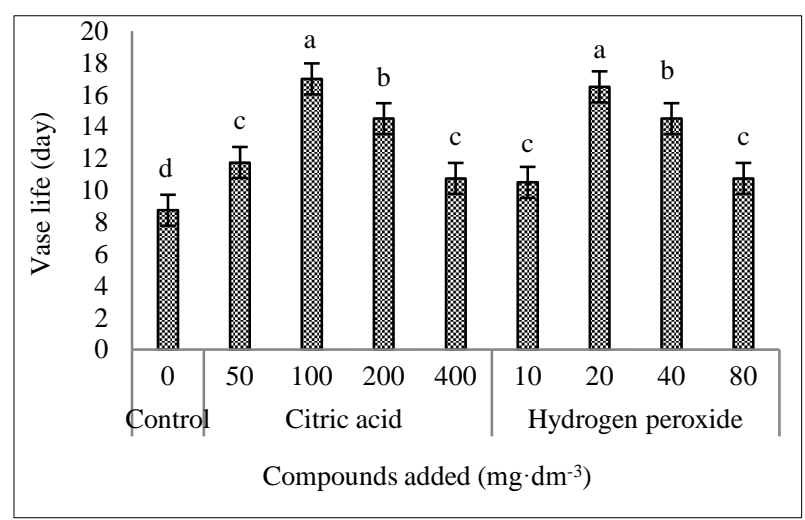

Fig. 7. Effects of citric acid and hydrogen peroxide on vase life of tuberose cut flowers. Bars indicated by the same letter do not differ significantly according to Duncan's multiple range test at $\mathrm{P}=0.05$, vertical lines $-\mathrm{SE}$

\section{Leaf chlorophyll content}

The compounds added to the water decreased chlorophyll loss significantly $\left(\mathrm{F}_{4,20}=43.564\right.$, $\mathrm{P}<0.01$ for $\mathrm{CA}$ and $\mathrm{F}_{4,20}=26.238, \mathrm{P}<0.01$ for $\mathrm{H}_{2} \mathrm{O}_{2}$ ), but the effect depended on the kind of chemical and its concentration. Although all treatments of $\mathrm{CA}$ and $\mathrm{H}_{2} \mathrm{O}_{2}$ significantly maintained the leaf chlorophyll content in cut flowers in comparison with the control at the end of experiment after three weeks; the highest leaf chlorophyll content was obtained at 100 and $200 \mathrm{mg} \cdot \mathrm{dm}^{-3}$ of $\mathrm{CA}$ and $20 \mathrm{mg} \cdot \mathrm{dm}^{-3}$ of $\mathrm{H}_{2} \mathrm{O}_{2}$ (Fig. 6). At these concentrations, chlorophyll content was double compared to control.

\section{Cut flowers vase life}

Using CA and $\mathrm{H}_{2} \mathrm{O}_{2}$ as the additions to water during storage significantly increased the vase life in cut flowers of the tuberose $\left(F_{4,20}=12.841\right.$, $\mathrm{P}<0.01$ and $\mathrm{F}_{4,20}=18.489, \mathrm{P}<0.01$, respectively) (Table 1). Furthermore, these results showed that effects of $\mathrm{CA}$ and $\mathrm{H}_{2} \mathrm{O}_{2}$ on the cut flower vase life was dependent on concentration (Fig. 7). The longest vase life was obtained at 100 and $200 \mathrm{mg} \mathrm{dm}^{-3} \mathrm{CA}$ (about 17 days) and 20 and $40 \mathrm{mg} \mathrm{dm}^{-3} \mathrm{H}_{2} \mathrm{O}_{2}$ (about 17 and 15 days, respectively), while 9 days in the control.

\section{DISCUSSION AND CONCLUSION}

After cutting, the fresh weight of flowering stem decreases, which is caused by the reduction of water uptake and increasing water loss through evaporation and respiration (Borochov et al. 1995; Rattanawisalanon et al. 2003; Mansouri 2012; Liao et al. 2012). Our results showed the significant effects of 50 and $100 \mathrm{mg} \cdot \mathrm{dm}^{-3}$ of CA and $20 \mathrm{mg} \cdot \mathrm{dm}^{-3}$ of $\mathrm{H}_{2} \mathrm{O}_{2}$ in increasing the water uptake and nonsignificant effects on fresh weight of tuberose cut flowers during postharvest time. Our results are in accordance with previous reports showing the effects of low $\mathrm{pH}$ on inhibition of bacterial growth and prevention the early wilting in Dendrobium by Rattanawisalanon et al. (2003) and in chrysanthemums by Mansouri (2012). Adding CA to vase solution caused low latex flow from the cut stem surface and delay in the closure of xylem (Imsabai et al. 2013). Liao et al. (2012) reported that addition of $\mathrm{H}_{2} \mathrm{O}_{2}$ in 
low concentration to vase solution improved the fresh weight of hybrid lily cut flowers and its antibacterial effect may be taken into account. Postharvest longevity of cut flowers is very important in their marketing and for economic value. Destruction of flowers by senescence is affected by some internal and external operants, such as genetics of cultivar, hormonal activity, polyamines, nutrient, and environmental factors (Leshem et al. 1998; Onozaki et al. 2001; Rogers 2006; Singh et al. 2008; Fanourakis et al. 2013; Teixeira da Silva et al. 2014; Perik et al. 2014). Furthermore, the browning and death of florets in cut flowers are the result of oxidative stress caused by polyphenoloxidase or peroxidases action that catalyze this process (Zhang et al. 2011). In tuberose, senescence symptoms are followed by browning and abscission of florets. The addition of $\mathrm{CA}$ and $\mathrm{H}_{2} \mathrm{O}_{2}$ to vase solution showed significant delay in browning and abscission of florets and, as a result, delaying senescence of tuberose cut flowers. Results showed that $100 \mathrm{mg} \mathrm{dm}^{-3} \mathrm{CA}$ and $20 \mathrm{mg}$ $\mathrm{dm}^{-3} \mathrm{H}_{2} \mathrm{O}_{2}$ had the greatest effect in preventing browning, abscission, and senescence of florets, which approved the former studies where low levels of $\mathrm{H}_{2} \mathrm{O}_{2}$ was effective in delaying the senescence of lily cut flowers and rice leaves (Liao et al. 2012; Hung et al. 2006). In addition, several studies have shown that reduction in the $\mathrm{pH}$ of the vase solution decreases the senescence rate in cut flowers (Kazemi et al. 2011; Zhang et al. 2011; Perik et al. 2014).

Chlorophyll content is a qualitative marker of senescence of cut flowers at postharvest time (Podd $\&$ van Staden 2002; Mutui et al. 2006; Seglie et al. 2013; Daneshi Nergi \& Ahmadi 2014). The results of the above studies showed a decrease in leaf chlorophyll content at postharvest time. According to findings of our research, delay in chlorophyll content loss improved the vase life of cut flowers. Both CA and $\mathrm{H}_{2} \mathrm{O}_{2}$ had a significant influence on delaying the chlorophyll loss during the tuberose postharvest time. The concentrations of $\mathrm{CA}-100,200$, and $400 \mathrm{mg} \cdot \mathrm{dm}^{-3}-$ and $\mathrm{H}_{2} \mathrm{O}_{2}-10,20$, and $40 \mathrm{mg} \cdot \mathrm{dm}^{-3}$ - induced a marked delay in decline of chlorophyll content, which is in agreement with other findings (Liao et al. 2012; Roberta Ansorena et al. 2014). A significant decrease in leaf RWC during vase life was obtained in the effect of the $\mathrm{CA}$ and $\mathrm{H}_{2} \mathrm{O}_{2}$ addition to the vase solution that inhibited the loss of water from leaves. Previous studies showed that $\mathrm{H}_{2} \mathrm{O}_{2}$ was involved in regulation of stomatal closure via abscisic acid activity and maintaining leaf water content (Zhang et al. 2001; Bright et al. 2006).

In the experiments described here, we have proven the positive effects of $\mathrm{CA}$ and $\mathrm{H}_{2} \mathrm{O}_{2}$ on morphological indices of tuberose cut flowers at postharvest. So, investigation on the physiological background is recommended for further studies.

\section{Acknowledgments}

The authors express their gratefulness to Mrs. S. Arast and N. Rahmani, the former bachelor students from the Department of Horticultural Science at the Zabol University, as well as thank Mr. A. Nikbakht from the Department of Horticulture Science at the Shiraz University.

\section{REFERENCES}

Alaey M., Babalar M., Naderi R., Kafi M. 2011. Effect of pre- and postharvest salicylic acid treatment on physio-chemical attributes in relation to vase-life of rose cut flowers. Postharvest Biology and Technology 61(1): 91-94. DOI: 10.1016/j.postharvbio.2011.02.002.

Bahadoran M., Salehi H., Eshghi S. 2012. Growth and flowering of tuberose as affected by adding natural zeolite to the culture medium. Journal of Plant $\mathrm{Nu}$ trition 35(10): 1491-1496. DOI: 10.1080/01904167.2012.689909.

Borochov A., Spiegelstein H., Porat R. 1995. Membrane lipids involved in the regulation of flower senescence. Acta Horticulturae 405: 240-245. DOI: 10.17660/Acta Hortic.1995.405.31.

Bright J., Desikan R., Hancock J.T., Weir I.S., Neill S.J. 2006. ABA-induced NO generation and stomatal closure in Arabidopsis are dependent on $\mathrm{H}_{2} \mathrm{O}_{2}$ synthesis. The Plant Journal 45: 113-122. DOI: 10.1111/j.1365-313X.2005.02615.

Coste S., Baraloto C., Leroy C., Marcon É., Renaud A., Richardson A.D. et al. 2010. Assessing foliar chlorophyll contents with the SPAD-502 chlorophyll meter: a calibration test with thirteen tree species of tropical rainforest in French Guiana. Annals of Forest Science 67(6): 607. DOI: 10.1051/forest/2010020.

Cuc N.T.T., Pilon M. 2007. An Aphelenchoides sp. nematode parasitic of Poliantes tuberosa in the Mekong Delta. Journal of Nematology 39(3): 248-257. 
Cuc N.T.T., Son N.T., Trung T.M., văn Trang N., Minh Đang L., Pilon M. 2010. Hot water treatment prevents Aphelenchoides besseyi damage to Polianthes tuberosa crops in the Mekong Delta of $\mathrm{Vi}$ etnam. Crop Protection 29: 599-602. DOI: 10.1016/j.cropro.2010.01.006.

Daneshi Nergi M.A., Ahmadi N. 2014. Effects of 1-MCP and ethylene on postharvest quality and expression of senescence-associated genes in cut rose cv. Sparkle. Scientia Horticulturae 166: 78-83. DOI: 10.1016/j.scienta.2013.12.015.

De Hertogh A., Le Nard M. 1993. The physiology of flower bulbs. Elsevier Science Publishers, Amsterdam, $812 \mathrm{p}$.

van Doorn W.G. 2010. Water relations of cut flowers. Horticultural Reviews. Wiley \& Sons, pp. 1-85.

Fanourakis D., Pieruschka R., Savvides A., Macnish A.J., Sarlikioti V., Woltering E.J. 2013. Sources of vase life variation in cut roses: a review. Postharvest Biology and Technology 78: 1-15. DOI: 10.1016/j.postharvbio.2012.12.001.

Hung K.T., Hsu Y.T., Kao C.H. 2006. Hydrogen peroxide is involved in methyl jasmonate-induced senescence of rice leaves. Physiologia Plantarum 127: 293-303. DOI: 10.1111/j.1399-3054.2006.00662.x.

Imsabai W., Leethiti P., Netlak P., van Doorn W.G. 2013. Petal blackening and lack of bud opening in cut lotus flowers (Nelumbo nucifera): role of adverse water relations. Postharvest Biology and Technology 79: 32-38. DOI: 10.1016/j.postharvbio.2012.12.017.

van Ieperen W., van Meeteren U., Nijsse J. 2002. Embolism repair in cut flower stems: a physical approach. Postharvest Biology and Technology 25: 114. DOI: 10.1016/S0925-5214(01)00161-2.

Jowkar M.M., Salehi H. 2005. Effects of different preservative solutions on the vase life of cut tuberose flowers at usual home conditions. Acta Horticulturae 669: 411-416. DOI: 10.17660/ActaHortic.2005.669.54.

Kazemi M., Hadavi E., Hekmati J. 2011. Role of salicylic acid in decreases of membrane senescence in cut carnation flowers. American Journal of Plant Physiology 6: 106-112. DOI: 10.3923/ajpp.2011.106.112.

Leshem Y.Y., Wills R.B.H., Ku V.V.V. 1998. Evidence for the function of the free radical gas - nitric oxide (NO) - as an endogenous maturation and senescence regulating factor in higher plants. Plant Physiology and Biochemistry 36: 825-833. DOI: 10.1016/S0981-9428(99)80020-5.

Liao W.B., Zhang M.L., Huang G.B., Yu J.H. 2012. Hydrogen peroxide in the vase solution increases vase life and keeping quality of cut Oriental $\times$ Trumpet hybrid lily 'Manissa'. Scientia Horticulturae 139: 32-38. DOI: 10.1016/j.scienta.2012.02.040.

Macarisin D., Droby S., Bauchan G., Wisniewski M. 2010. Superoxide anion and hydrogen peroxide in the yeast antagonist - fruit interaction: a new role for reactive oxygen species in postharvest biocontrol? Postharvest Biology and Technology 58(3): 194-202. DOI: 10.1016/j.postharvbio.2010.07.008.

Macnish A.J., Leonard R.T., Nell T.A. 2008. Treatment with chlorine dioxide extends the vase life of selected cut flowers. Postharvest Biology and Technology 50: 197-207. DOI: $10.1016 /$ j.postharvbio.2008.04.008.

Mansouri H. 2012. Salicylic acid and sodium nitroprusside improve postharvest life of chrysanthemums. Scientia Horticulturae 145: 29-33. DOI: 10.1016/j.scienta.2012.07.016.

van Meeteren U., Arévalo-Galarza L., van Doorn W.G. 2006. Inhibition of water uptake after dry storage of cut flowers: role of aspired and wound-induced processes in Chrysanthemum. Postharvest Biology and Technology 41(1): 70-77. DOI: $10.1016 /$ j.postharvbio.2006.03.005.

van Meeteren U., van Gelder A., van Ieperen W. 2005. Effect of growth conditions on postharvest rehydration ability of cut chrysanthemum flowers. Acta Horticulturae 669: 287-295. DOI: 10.17660/ActaHortic.2005.669.38.

Mutui T.M., Emongor V.E., Hutchinson M.J. 2006. The effects of gibberellin $4+7$ on the vase life and flower quality of Alstroemeria cut flowers. Plant Growth Regulation 48: 207-214. DOI: 10.1007/s10725006-0014-6.

Neill S., Desikan R., Hancock J. 2002. Hydrogen peroxide signalling. Current Opinion in Plant Biology 5(5): 388-395. DOI: 10.1016/S1369-5266(02)00282-0.

Onozaki T., Ikeda H., Yamaguchi T. 2001. Genetic improvement of vase life of carnation flowers by crossing and selection. Scientia Horticulturae 87: 107-120. DOI: 10.1016/S0304-4238(00)00167-9.

Peng L., Yang S., Li Q., Jiang Y., Joyce D.C. 2008. Hydrogen peroxide treatments inhibit the browning of fresh-cut Chinese water chestnut. Postharvest Biology and Technology 47(2): 260-266. DOI: 10.1016/j.postharvbio.2007.07.002.

Perik R.R.J., Razé D., Ferrante A., van Doorn W.G. 2014. Stem bending in cut Gerbera jamesonii flowers: effects of a pulse treatment with sucrose and calcium ions. Postharvest Biology and Technology 98: 7-13. DOI: 10.1016/j.postharvbio.2014.06.008. 
Podd L.A., van Staden J. 2002. Physiological response and extension of vase life of cut carnation flowers treated with ethanol and acetaldehyde. I. Chlorophyll content and carbohydrate status. Plant Growth Regulation 38: 99-105. DOI: 10.1023/A:1021267712167.

Rattanawisalanon C., Ketsa S., van Doorn W.G. 2003. Effect of aminooxyacetic acid and sugars on the vase life of Dendrobium flowers. Postharvest Biology and Technology 29: 93-100. DOI: 10.1016/S0925-5214(02)00242-9.

Roberta Ansorena M., Rosario Moreira M., Roura S.I. 2014. Combined effect of ultrasound, mild heat shock and citric acid to retain greenness, nutritional and microbiological quality of minimally processed broccoli (Brassica oleracea L.): an optimization study. Postharvest Biology and Technology 94: 113. DOI: 10.1016/j.postharvbio.2014.02.017.

Rogers H.J. 2006. Programmed cell death in floral organs: how and why do flowers die? Annals of Botany 97: 309-315. DOI: 10.1093/aob/mcj051.

Rubinstein B. 2000. Regulation of cell death in flower petals. Plant Molecular Biology 44: 303-318. DOI: 10.1023/A:1026540524990.

Sairam R.K., Rao K.V., Srivastava G.C. 2002. Differential response of wheat genotypes to long term salinity stress in relation to oxidative stress, antioxidant activity and osmolyte concentration. Plant Science 163: 1037-1046. DOI: 10.1016/S01689452(02)00278-9.

Sankhla N., Mackay W.A., Davis T.D. 2003. Nitric acid enhances flower abscission and senescence in cut racemes of Lupinus havardii Wats. Proceedings of the Plant Growth Regulation Society of America 30: $130-131$.

Seglie L., Devecchi M., Trotta F., Scariot V. 2013. $\beta-C y-$ clodextrin-based nanosponges improve 1-MCP efficacy in extending the postharvest quality of cut flowers. Scientia Horticulturae 159: 162-165. DOI 10.1016/j.scienta.2013.05.019.
Singh A., Kumar J., Kumar P. 2008. Effects of plant growth regulators and sucrose on post harvest physiology, membrane stability and vase life of cut spikes of gladiolus. Plant Growth Regulation 55: 221-229. DOI: 10.1007/s10725-008-9278-3.

Shahri W., Tahir I. 2011. Flower senescence-strategies and some associated events. Botanical Review 77: 152-184. DOI: 10.1007/s12229-011-9063-2.

Shimizu-Yumoto H., Ichimura K. 2010. Combination pulse treatment of 1-naphthaleneacetic acid and aminoethoxyvinylglycine greatly improves postharvest life in cut Eustoma flowers. Postharvest Biology and Technology 56: 104-107. DOI: 10.1016/j.postharvbio.2009.10.001.

Taha L.S., Eid R.A. 2011. Stimulation effect of some bioregulators on flowering, chemical constituents, essential oil and phytohormones of tuberose (Polianthes tuberos L.). Journal of American Science 7(5): 165-171. DOI: 10.7537/marsjas070511.25.

Teixeira da Silva J.A., Aceto S., Liu W., Yu H., Kanno A. 2014. Genetic control of flower development, color and senescence of Dendrobium orchids. Scientia Horticulturae 175: 74-86. DOI: 10.1016/j.scienta.2014.05.008.

Weaver L.M., Gan S., Quirino B., Amasino R.M. 1998. A comparison of the expression patterns of several senescence-associated genes in response to stress and hormone treatment. Plant Molecular Biology 37: 455-469. DOI: 10.1023/A:1005934428906.

Zhang H., Hu S.L., Zhang Z.J., Hu L.Y., Jiang C.X., Wei S.T. et al. 2011. Hydrogen sulfide acts as a regulator of flower senescence in plants. Postharvest Biology and Technology 60: 251-257. DOI: 10.1016/j.postharvbio.2011.01.006.

Zhang X., Zhang L., Dong F., Gao J., Galbraith D.W., Song C.P. 2001. Hydrogen peroxide is involved in abscisic acid-induced stomatal closure in Vicia faba. Plant Physiology 126(4): 1438-1448. DOI: 10.1104/pp.126.4.1438 